\title{
Beden Eğitimi Öğretmenliği Bölümlerinin Yeterliliği İle İlgili Öğretmen Görüşleri*
}

\section{Teacher Opinions about Physical Education Teacher's Departmants}

\author{
Sinan Uğraş ${ }^{a^{* *}}$, Mehmet Güllü ${ }^{b}$ \\ ${ }^{a}$ Dr., Milli Eğitim Bakanlığı, Sümer Ortaokulu, 44280, Malatya/Türkiye. \\ ORCID: 0000-0003-0792-1497

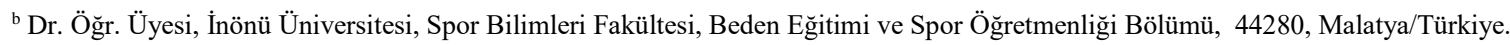 \\ ORCID: 0000-0002-0930-7178
}

\section{MAKALE BILLGISİ}

Makale Geçmişi:

Başvuru tarihi: 31 Mayıs 2018

Düzeltme tarihi: 23 Ağustos 2018

Kabul tarihi: 05 Eylül 2018

\section{Anahtar Kelimeler:}

Beden Eğitimi Öğretmeni

Nitel Araştırma

Öğretmenlik Bölümü

Yeterlilik

\section{ARTICLE INFO}

\section{Article history:}

Received 31 May 2018

Received in revised form 23 August 2018

Accepted 05 September 2018

\section{Keywords:}

Adequacy

Physical Education Teacher

Qualitative Research

Teachers Departmant

\section{ÖZ}

$\mathrm{Bu}$ araştırmanın amacı beden eğitimi ve spor öğretmenliği bölümlerinin yeterliliği hakkında öğretmen görüşlerini incelemektir. Araştırmada karma yöntemlerden yakınsayan paralel desen kullanılmıştır. Nitel araştırma grubunu, 20 beden eğitimi öğretmeni oluştururken nicel araştırma grubunu 283 beden eğitimi öğretmeni oluşturmaktadır. Veri toplama aracı olarak, "yarı yapılandırılmış görüşme formu" ve "Beden Eğitimi ve Spor Öğretmenliği Bölümlerinin Yeterliliği Ölçeği (BESÖBYÖ)" kullanılmıştır. Araştırma sonucunda beden eğitimi öğretmenleri mezun oldukları lisans programlarının Milli Eğitim Bakanlığına bağlı okulların imkân ve şartlarına uygun nitelikte beden eğitimi öğretmeni yetiştirmediklerini ifade etmişlerdir. Ayrıca lisans derslerini yürüten ögretim elemanlarının yeterli sayıda olmadıkları ve bazı derslerde nitelik bakımından yetersiz kaldıklarını ileri sürmüşlerdir. Beden eğitimi öğretmenleri beden eğitimi ve spor öğretmenliği bölümlerinin tesis ve sosyal imkânlar açısından problemlerin olduğunu belirtmişlerdir.

\section{A B S T R A C T}

The aim of this study is to investigating of teachers' views on the adequacy of physical education and sports departments. The study was used the convergent parallel design, one of the mixed method research designs. As inquiry group, for maximum variety samples 20 physical education teachers working at Provincial Directorate of National Education in Malatya, is composed and for qualitative search method 283 physical education teachers are chosen. For data gathering tool, semi structured form. and "Adequacy of Physical Education and Sports Departments Scale" (APESDS) is performed. At the end of the research, physical education teacher express that licence programs they graduate from don't train physical education teachers in accordance with their conditions and opportunities. Also, they introduce that instructors who carry out undergraduate courses are not enough and they are inadequate in terms of quality some subjects. Physical education teachers state that physical education and sports teaching parts have problems in terms of facilities and social facilities

\section{Giriş}

Günümüzde eğitim programları içerisinde beden eğitimi dersi çocukların fiziksel, duyuşsal ve bilişsel özelliklerini gelişmelerini sağlamada önemli bir role sahiptir. Beden eğitimi “fiziksel etkinliklerin kullanıldĭ̆g ĕgitimsel bir süreç olduğu kadar, bireylerin gereksinim duyduğu tutum, bilgi ve becerilerin optimal düzeyde gelişmesine de katkıda bulunan " bir süreç olarak ifade edilmiştir (Wuest ve Buacher (1999)'den aktaran: Heper vd., 2012). Özmen (1999) ise beden eğitimini, eğitim biliminde olduğu gibi insan davranış ve alışkanlıklarına yönelik "pedagojik bir disiplin, bir bilim ve sanat dalı" olarak görmektedir. Beden eğitimi dersi amaçlarının programa uygun bir şekilde yürütülebilmesi için öğretmen niteliği ön plana çıkar. Öğretmen, eğitim sürecindeki en etkili, stratejik ve dinamik öğelerden birisidir

\footnotetext{
* Bu çalışma, 2013 yılında İnönü Üniversitesi Sağlık Bilimleri Enstitüsü tarafindan kabul edilen “Beden Ĕgitimi ve Spor Öğretmenliği Bölümlerinin Yeterliliği Hakkında Öğretmen Görüşlerinin Incelenmesi” adlı Yüksek Lisans tezinden türetilmiş ve İnönü Üniversitesi Bilimsel Araştırma Projeleri Birimi tarafından (BAP 2012/42) tarafindan desteklenmiştir.

** Sorumlu yazar/Corresponding author.

e-posta: sinanugras@gmail.com
} 
ve eğitim sisteminin kalitesini belirleyici faktörlerin başındadır (Barlı, 2005; Doğan ve Koçak, 2014; Öztürk, 2013). Nitelikli bir beden eğitimi öğretmeninde olması gereken özelliklerden bahsedildiğinde; mesleki bilgisi ve becerisi, sportmen olması, iyi bir görüntüye sahip olması, insan ilişkilerinde iyi olması, eleştirel olması, iyi bir disiplin anlayışına sahip olması, spor yapmaya merak uyandırması gibi birçok özelliğe sahip olması gerekmektedir (Demirhan, 2003; Friedman, 1983).

Öğretmenin niteliğini belirleyen etmenlerin ilki öğretmen yetiştiren kurumun kalitesidir. Öğretmen yetiştiren kurumların niteliği, yürütülen programın içeriği, zamana uygunluğu, tesis ve donanımı, öğretim elemanlarının kalitesi, bu kurumlardan mezun olan öğretmenlerin niteliğini doğrudan etkiler. Türkiye'de beden eğitimi öğretmeni yetiştirme çalışmaları içerisinde farklılıklar göstermiştir. Cumhuriyetin ilk yıllarında 1926-1930 yılları arasında kurslar vasıtası ile beden eğitimi ve spor öğretmeni yetiştirilmiş daha sonra 1932-1977 yıllarında eğitim enstitüleri beden eğitimi öğretmeni yetiştirmiştir. Daha sonraki yıllarda sirasıyla, spor akademileri (1974-1982), beden eğitimi ve spor enstitüleri (1978-1982) ve en son olarak üniversiteler beden eğitimi öğretmeni yetiştirmeye başlamıştır (Bilge, 1989). Günümüzde ise üniversiteler içerisinde yer alan Beden Eğitimi ve Spor Yüksekokulları, Eğitim Fakülteleri, Spor Bilimleri ve Teknolojisi Yüksekokulu, Spor bilimleri Fakültelerin bünyelerinde beden eğitimi öğretmeni yetiştirilmektedir. Beden eğitimi öğretmenliği bölümleri, ÖSYM (2017) yerleştirme k1lavuzuna göre beden eğitimi öğretmenliği bölümlerinin sayılarının 84'e ulaştığı görülmektedir. Beden eğitimi yetiştiren bölümlerin açılma hızı düşünüldüğünde bunun bir takım problemleri de beraberinde getireceği söylenebilir.

Koçak ve Tuncel (2011) beden eğitimi ve spor yüksekokullarında stratejik yönetim uygulaması çalışmasında, okulun zayıf yönleri içerisinde tesis ve laboratuvarların var olan ihtiyacı karşılamadığı ve tesislerin bölümlere ait olmadığı sonucunu ortaya koymuşlardır. Can ve Durukan (1999) cumhuriyetten günümüze öğretmen yetiştirilmesi çalışmasında öğretmen yetiştiren kurumların fiziki yetersizlerinden ve kapasitesinin üzerinde öğrenci alınmaması gerektiğinden bahsetmişlerdir. Dohman ve Özmaden (2008) beden eğitimi ve spor öğretmenliği bölümlerinde öğretmen yetiştirme sorunları araştırdığı çalışmasında öğretmen adayları tesis ve malzeme eksikliği olduğunu ifade etmişlerdir.

Açıkada (1992) beden eğitimi ve spor eğitimi veren kurumlarda tesis ve laboratuvar eksikliği olduğunu söylemiştir. Yanık (2007) beden eğitimi ve spor yüksekokullarının toplam kalite yönetimi bakımından öğretim elemanları ve öğrenciler tarafindan değerlendirdiğ araştırmasında bölümlerin, tesis ve malzeme eksikliği yaşadığını belirtmiştir. Çiçek ve Bizati (2002) stajyer beden eğitimi öğretmenleri ile ilgili yaptığı araştırmada öğretmenlerin problem yaşadıkları konuların yıllık plan, ders planı ve günlük ders planı hazırlama konusunda olduğu sonucuna ulaşmıştır. Ayrıca stajyer beden eğitimi öğretmenlerinin sınıf içi disiplin ve uygun öğretim metodu konusunda problemler yaşadıkları sonucuna ulaşılmıştır. $\mathrm{Bu}$ sonuçlar yeni mezun olmuş olan beden eğitimi öğretmenlerinin mesleğe hazır olarak başlamadıklarının bir göstergesidir.
Beden eğitimi öğretmenli bölümlerinin sayısı son yıllarda hızla artmış ve 2018 sonunda 84 adet beden eğitimi ve öğretmenliği bölümü mevcut olduğu görülmüştür (ÖSYM, 2017). Nitelikli bir beden eğitimi öğretmeni yetiştirmenin en önemli unsurlarından bir tanesi öğretmenin yetiştiği kurumdur. Bu araştırma ile Milli Eğitim Bakanlığına bağlı okullarda çalışan öğretmenlerin mezun oldukları beden eğitimi öğretmenliği bölümlerinin yeterliliği hakkında görüşlerini incelemektir.

$\mathrm{Bu}$ bağlamda öğretmenlerin, mezun oldukları beden eğitimi ve spor öğretmenliği bölümlerinin okudukları döneme ait program, öğretim elemanları, tesis bakımından görüşlerini alarak bu kurumların beden eğitimi öğretmeni yetiştirmedeki yeterliliklerinin tespiti amaçlanmıştır.

\section{Yöntem}

Bu bölümde araştırma modeli, araştırma grubu, veri toplama araçları, verilerin analizi ve araştırmanın etik boyutu yer almaktadir.

\subsection{Araştırma Modeli}

Araştırma, beden eğitimi öğretmenlerinin mezun oldukları bölümlerin yeterliliği hakkında düşüncelerinin tespit edilmesi amacıyla karma yöntem araştırma desenlerinden nitel ve nicel verilerin eş zamanlı olarak toplandı ̆̆ 1 , ayrı ayrı analiz edildiği ve elde edilen nitel ve nicel sonuçların birlikte yorumlandığı yakınsayan paralel desen kullanılmıştır (Creswell ve Plano Clark, 2015). Bu araştırmada nitel bölümde durum çalışması kullanılmıştır. Durum çalışması araştırması, araştırmacının gerçek yaşam, güncel bir durum ya da belli bir zaman içerisindeki durumun derinlemesine betimlemelerin yapıldığı veya durum temalarının ortaya koyulduğu bir yaklaşımdır (Meriam, 2015; Cresswell, 2016). Araştırmada beden eğitimi öğretmenliği bölümlerinin tesis, program ve öğretim elemanı yeterliliği bakımından derinlemesine incelenmiştir. Araştırmanın nicel bölümünde ise beden eğitimi öğretmenlerinin cinsiyetleri ve yaşlarına göre bir farklılık olup olmadığının belirlenmesi için nedensel karşılaştırma kullanılmıştır. Nedensel karşılaştırma, iki veya daha fazla değişken arasındaki ilişkilerin varlığını veya derecesini inceleyen, neden-sonuç ile ilgili ipuçları elde etmek ve incelenen olguları daha iyi anlayabilmek amacıyla yapılan araştırmalardır (Büyüköztürk, 2017).

\subsection{Araştırma Grubu}

Araştırmada karma yöntem kullanıldığından nitel araştırma grubu ve nicel araştırma grubu ayrı ayrı oluşturulmuştur.

\subsubsection{Nitel Araştırma Grubu}

Beden eğitimi öğretmenlerinin beden eğitimi öğretmenliği bölümleri hakkında farklı görüşlerinin alınabilmesi ve genelleme yapılabilmesi için amaçlı örnekleme yöntemlerinden maksimum çeşitlilik örnekleme yöntemi uygulanmıştır. Amaçlı örnekleme, kaynakların etkili bir biçimde kullanılması için bilgi yönünden zengin durumların belirlenmesi ve seçilmesi için nitel araştırmalarda sıklıkla kullanılan bir yöntemdir (Patton, 2002). Amaçlı örnekleme yöntemlerinden maksimum çeşitlilik kullanılmıştır. Maksimum çeşitlilik çalışmalarında, çeşitlilik arz eden durumlar arasında ortak olguların tespit edilmesi ve bu çeşitliliğe göre problemin farklı boyutlarını ortaya koymak 
amaçlanır (Yıldırım ve Şimşek, 2011). Beden eğitimi öğretmenlerinin hizmet yılları, yaşı, cinsiyetleri, mezun olduğu üniversitesi gibi farklı niteliklere sahip katılımcilar seçilmiştir. Araştırmaya 2012-2013 eğitim öğretim yılında Malatya Milli Eğitim Müdürlüğüne bağlı devlet ve özel okullarında çalışan 20 beden eğitimi öğretmeni katılmıştır.

Tablo 1. Araştırmanın Nitel Bölümüne Katılan Beden Eğitimi Öğretmenlerinin Nitelikleri

\begin{tabular}{ccccc}
\hline Katılımcı Kod & Cinsiyet & Yaş & $\begin{array}{c}\text { Hizmet } \\
\text { Y1lı }\end{array}$ & $\begin{array}{c}\text { Mezun Olduğu } \\
\text { Üniversite }\end{array}$ \\
\hline B.E.Ö.1 & Erkek & 23 & 1 & Adnan Menderes Ü. \\
B.E.Ö.2 & Erkek & 24 & 2 & Yakındoğu Unv. \\
B.E.Ö.3 & Kadın & 27 & 4 & Niğde Ünv. \\
B.E.Ö.4 & Erkek & 28 & 5 & Dicle Unv. \\
B.E.Ö.5 & Erkek & 29 & 6 & Ankara Unv. \\
B.E.Ö.6 & Kadın & 29 & 7 & Erciyes Unv. \\
B.E.Ö.7 & Erkek & 30 & 7 & Mustafa Kemal U. \\
B.E.Ö.8 & Erkek & 31 & 8 & Inönü Unv. \\
B.E.Ö.9 & Erkek & 32 & 9 & Akdeniz Unv. \\
B.E.Ö.10 & Erkek & 32 & 10 & Van Yüzüncü y1l U. \\
B.E.Ö.11 & Kadın & 34 & 12 & Kırıkale Unv. \\
B.E.Ö.12 & Erkek & 35 & 12 & Kafkas Unv. \\
B.E.Ö.13 & Erkek & 37 & 13 & Anadolu Unv. \\
B.E.Ö.14 & Kadın & 38 & 15 & Ege Ünv. \\
B.E.Ö.15 & Erkek & 40 & 18 & Atatürk Unv. \\
B.E.Ö.16 & Erkek & 42 & 20 & Hacette Unv. \\
B.E.Ö.17 & Kadın & 45 & 21 & Uludağ Unv. \\
B.E.Ö.18 & Kadın & 48 & 23 & C Celal Bayar Unv. \\
B.E.Ö.19 & Erkek & 50 & 24 & Marmara Unv. \\
B.E.Ö.20 & Erkek & 55 & 30 & Gazi Unv. \\
\hline
\end{tabular}

Tablo 1'e göre üzere beden eğitimi öğretmenleri farklı mezuniyet y1llarına ve farklı üniversitelerden mezun olmalarına göre maksimum çeşitlilik yöntemine göre seçilmiştir. Bu şekilde farklı üniversitelerin program ve üniversite niteliklerinin farklılıkları ve ortak problemlerinin incelenmesi amaçlanmıştır

\subsubsection{Nicel Araştırma Grubu}

Nicel veriler için araştırma grubu 2012-2013 eğitim öğretim yılında Malatya ilinde görev yapan 283 beden eğitimi öğretmeni oluşturmaktadır. Öğretmenlerin kişisel özellikleri aşağıda verilmiş̧ir.

Tablo 2. Araştırmanın Nicel Bölümüne Katılan Beden Eğitimi Öğretmenlerinin Nitelikleri

\begin{tabular}{llcc}
\hline BE. Öğretmenlerinin Kişisel Özellikleri & $\mathrm{f}$ & $\%$ \\
\hline \multirow{2}{*}{ Cinsiyet } & Erkek & 200 & 70,7 \\
\cline { 2 - 4 } & Kadın & 83 & 29,3 \\
\hline \multirow{4}{*}{ Yaş } & 30 yaş ve altı & 45 & 15,9 \\
\cline { 2 - 4 } & $31-35$ yaş & 118 & 41,7 \\
\cline { 2 - 4 } & $36-40$ yaş & 100 & 35,3 \\
\cline { 2 - 4 } & 41-45 yaş & 11 & 3,9 \\
\cline { 2 - 4 } & 45 yaş ve üzeri & 9 & 3,2 \\
\hline Toplam & & & 100 \\
\hline
\end{tabular}

\subsection{Veri Toplama Araçları}

Araştırmada kullanılan nitel veri toplama aracı ve nicel veri toplama aracı bu bölümde verilmiştir.

\subsubsection{Nitel Veri Toplama Aracl}

Çalışmanın nitel bölümünde araştırmacılar tarafından geliştirilen ve 18 sorudan oluşan yarı yapılandırılmış görüşme formu ile röportaj yapılmıştır. Yarı Yapılandırılmış görüşme formu araştırmacı görüşülene yöneteceği belli baş̧ı sorular hazırlar ve bu soruları sorar. Ancak görüşme sırasında yeni sorarlar sorma gereğini de hissederse onları da görüşülen kişiye yöneltir (Yıldırım ve Şimşek, 2011) Mülakat formu taslak soruları alanında uzman 3 ögretim üyesine gönderilmiş gerekli düzetmeler yapıldıktan sonra iki beden eğitimi öğretmeni ile deneme görüşmeleri yapıldıktan sonra son halini almıştır. Görüşmeler okulların spor odalarında yapilmış olup yaklaşık 1-1,5 saat sürmüştür. Görüşmeler veri kaybının yaşanmaması için ses kayıt cihazı ile kayıt altına alıp Word dosyasına aktarılmıştır. Yazılı dosyalar Nvivo 9.00 paket programı yüklenmiştir.

Araştırmanın nitel bölümünün iç geçerliliği için katılımcı teyidi kullanılmıştır. $\mathrm{Bu}$ amaçla, beden eğitimi öğretmenlerine görüşmelerin yazılı kayıtları verilerek bildirim ve teyitleri alınmıştır (Merriam, 2016, 265). Araştırmanın güvenilirliği için beden eğitimi öğretmenlerinin yarı-yapılandırılmış görüşme formunda yer alan açık uçlu sorulara verdikleri cevaplar nitel araştırma konusunda uzman başka bir öğretim üyesi tarafindan incelenmiş "görüş birliği" ve "görüş ayrıllğı" olan kodlar tartışılmış ve gerekli düzenlemeler yapılmıştır. Araştırmanın güvenilirlik hesaplaması için Miles ve Huberman'ın önerdiği güvenirlik formülü kullanılmıştır (Miles ve Huberman, 1994). Güvenirlik = Görüş Birliği / (Görüş Birliği + Görüş Ayrılığı) Güvenilirlik katsayısı 0,84 çıkmıştır. Uzmanlar araştırma için güvenirlik hesabının 0.70 'in üzerinde çıkmasını güvenilir kabul etmektedir (Miles ve Huberman, 1994).

\subsubsection{Nicel Veri Toplama Aracı}

Çalışmanın nicel bölümünde araştırmacılar tarafından geliştirilen "Beden Eğitimi ve Spor Öğretmenliği Bölümlerinin Yeterliliği Ölç̧eği” (BESÖBYÖ) kullanılmıştır (Uğraş, 2013). Ölçek 21 maddeden oluşan, üç faktörlü (öğretim programı yeterliliği, öğretim elemanı yeterliliği, tesis yeterliliği) ve likert tipi 5'li dereceli tipte ölçekleme türüne sahiptir.

\subsection{Verilerin Analizi}

Araştırmada nitel ve nicel veri toplama araçları ile ayrı ayrı toplanan verilere ayrı ayrı analizleri yapılmıştır.

\subsubsection{Nitel Veri Analizi}

Görüşmeler sonucu elde edilen nitel veriler Nvivo 9.00 yüklendikten sonra betimsel ve içerik analizleri yapılmıştır. Betimsel analizde araştırmacılar ayrıntılı tanımlamalar oluşturmakta, kodlar, kategoriler ve temalar aracılığ kendi görüşlerinin ya da literatürdeki bilgilerin ışında yorumlanır (Cresswell, 2016). Beden eğitimi öğretmenleriyle yapılan görüşmeler sonucu elde edilen veriler kod, kategori ve temalara ayrılarak içerik analizleri yapılmıştır. Katılımcılara B.E.Ö.1, B.E.Ö.4 vb. kodlar verilmiştir.

\subsubsection{Nicel Veri Analizi}

Nicel verilerin analizi için BESÖBYÖ'nin Öğretim Programı Yeterliliği, Öğretim Elemanı Yeterliliği ve Tesis Yeterliliği alt boyutlarından elde edilen verilerin normal dağıılıp dağılmadıkları Kolmogrov-Smirnov testi ile 
sınanmış ve bu sınama sonucunda verilerin normal dağılmadıkları saptanmıştır. $\mathrm{Bu}$ nedenle istatistikî analizlerde nonparametrik testlerin uygulanmasına karar verilmiş ve böylece ikili karşılaştırmalar için Mann- Whitney U Testi ve çoklu karşılaştırmalar için Kruskal-Wallis H Testi ve Bonferroni düzeltmeli Mann-Whitney U Testi yöntemleri kullanılmıştır. Anlamlılık değeri için $\alpha=0.05$ değeri kritik nokta olarak belirlenmiştir.

\subsection{Araștırmanın Etik Boyutu}

Araştırmanın yapılabilmesi için Malatya Milli Eğitim Müdürlüğünden gerekli izinler alınmıştır. Ayrıca katılımcı öğretmenlere "Bilgilendirilmiş Gönüllü Olur Formu" imzalatılmıştır.

\section{Bulgular ve Yorum}

Araştırmanın nitel bölümünde ise beden eğitimi öğretmenlerinin mezun oldukları bölümlerle ilgili düşüncelerinin içerik analizi yapılmıştır. Araştırmanın nicel boyutunda, BESÖBYÖ'den elde edilen veriler analiz edilmiştir. Beden eğitimi öğretmenlerinin mezun oldukları beden eğitimi öğretmenliği bölümlerinin yeterliliği ile ilgili cinsiyetlerine ve yaşlarına göre anlamlı bir farklılık gösterip göstermediği sorusuna yanıt aranmıştır.

\subsection{Nitel bulgular}

İçerik analizi sonucunda öğretmenlerin beden eğitimi ve spor bölümü yeterlilikleri ile ilgili görüşleri “Öğretim Program Yeterliliği”, "Öğretim Elemanı Yeterliliği” ve "Tesis ve Sosyal İmkânların Yeterliliği" olarak üç tema biçiminde belirlenmiştir. Bu bölümde temalara ait kategoriler, kodlar ve bunlara ait kodlamalar verilmiştir.

\section{Öğretim Programı Yeterliliği Teması}

"Öğretim programı yeterliliği teması" 7 kategori ve bunlara bağl1 9 kodlamadan oluşmuştur. Bu bölümde kategorilerin isimleri ve frekans sayıları verilmiştir. Bu kategoriler; "Milli Eğitim Bakanlığı şartlarının üniversite eğitimi ile farklılığı (f=12)", "Öğretmenliğe hazır hissetmeme (f=11)", "Spor derslerini yetersiz görme $(\mathrm{f}=11)$, "Mezuniyetten sonra kendini geliştirme ihtiyacı ( $\mathrm{f}=10$ )" Öğretim yöntemlerinin yetersiz alımı $(\mathrm{f}=8)$ "Genel kültür derslerini gerekliliği (f=18) ve "Teorik dersleri gerekli görmedir. (f=12)"Milli Eğitim Bakanlığ 1 şartlarının üniversite eğitimi ile farklılığ alt kategorisinde beden eğitimi öğretmenleri verdikleri cevaplarda okudukları dönemde verilen eğitimin göreve başladıktan sonra aldıkları eğitimin uygulamada farklılıklar gösterdiğini belirtmişlerdir. Milli eğitim bakanlığının çok önemli olarak gördükleri bazı bilgilerin üniversitede hiç almadıklarını ya da çok az aldıklarını ifade etmişlerdir. B.E.Ö.5: "Hentbol, basketbol, ritim eğitimi ve dans, yüzme, tenis, masa tenisi bu dersleri alamadım diğer dersleri seçince bu dersleri hiç alamadım bu dersler zorunlu olmall. Öğretmenlikte her türden branş karşımıza çıkıyor. Birazda olsa bilgi sahibi olmamız gerekir bence”. Beden eğitimi öğretmenleri üniversitede almadıkları veya eksik aldıkları dersler nedeniyle göreve başladıkları ilk yıllarda zorluklar yaşadıkları söylenebilir. Öğretmenliğe hazır hissetmeme kategorisinde beden eğitimi öğretmenleri göreve başladıkları ilk dönemlerde öğretmenliğe kendilerini çok hazır hissetmediklerini belirtmişlerdir. B.E.Ö.2: "Şunu söyleyebilirim ögretmenliğe yeni başladım fakat birçok konuda kendimi eksik hissediyorum. Bildiklerimi de nasil aktaracă̆ım konusunda kendimi çok tecrübesiz hissediyorum”. Milli Eğitim Bakanlığı şartları, öğretmenlik programının içeriği, öğretmenlik uygulamasının yetersizliği, ders içeriği gibi nedenler göstererek kendilerini hazır hissetmedikleri sonucu ortaya çıkmıştır. Spor derslerini yetersiz görme kategorisinde beden eğitimi öğretmenleri spor derslerini eğitim ve öğretim dönemleri boyunca istediği seçmeli dersi alamama, ders içeriği, derslerin dağılımı, kredi sayısı, oyun kuralları ve antrenörlük bilgisi açısından yeterli eğitimi almadıklarını düşünmektedirler.

Şekil 1. Öğretim Programı Yeterliliği Teması

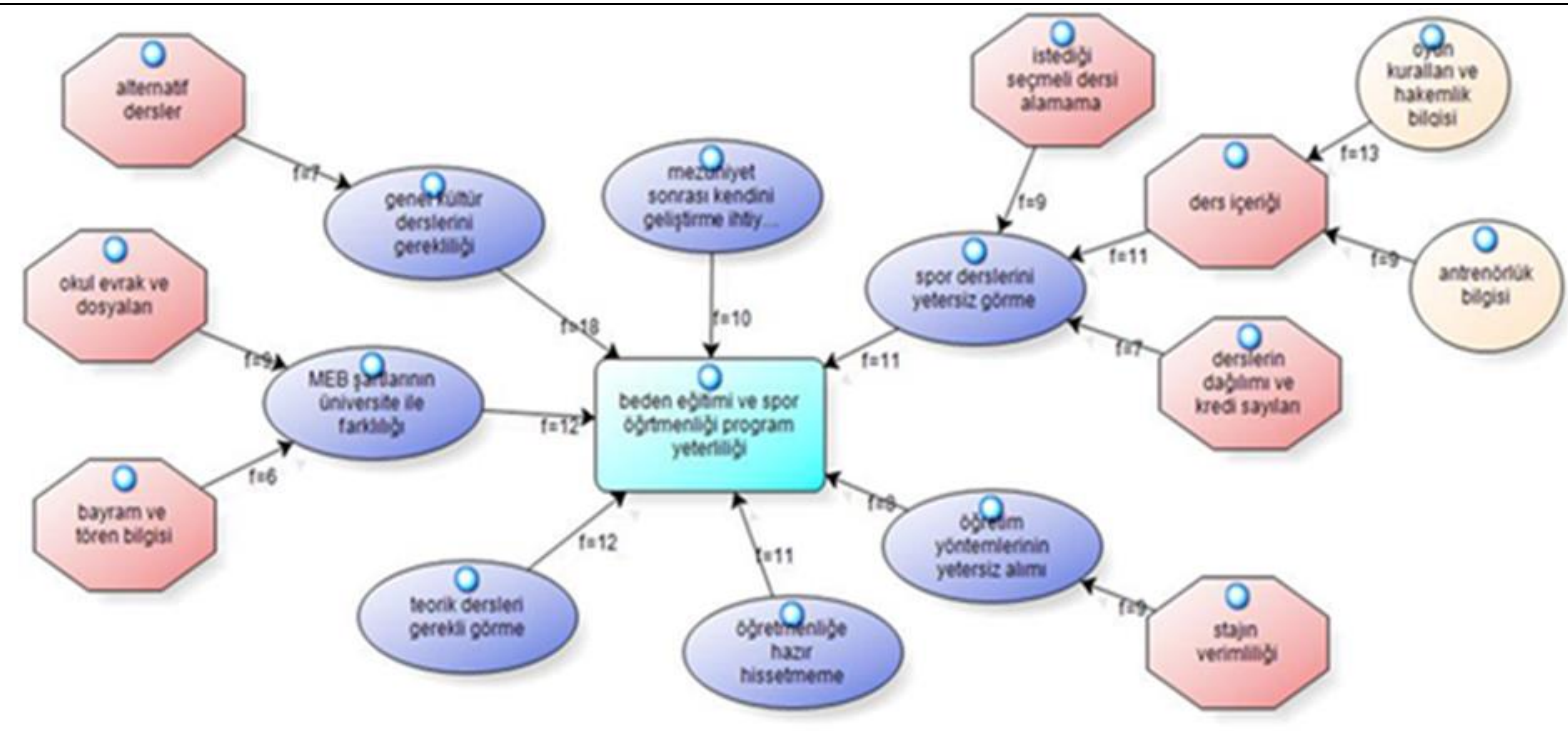


B.E.Ö.8: "Görmediğim uygulamalı dersler çoğunlukta. Bazı temel branşlarl seçtiğimiz zaman diğerlerini seçemiyorduk. Bu yüzden voleybol dersini hiç almadım. Öğretmenlikte bunları uygulamakta zorluk yaşadım.” Bu ifadeye bakıldığ zaman öğretmenlik programının eksikliğinden kaynaklanan problemlerin yaşandığı görülmektedir. Mezuniyetten sonra kendini geliştirme ihtiyacı alt boyutunda öğretmenler ifadelerinde lisans dönemindeki eğitimin açığını kapatabilmek için çeşitli yollardan kendilerini geliştirme ihtiyacının doğduğunu belirtmişlerdir. B.E.Ö.1: "Daha yeni ögretmen olduğum için eksikliklerim yavaş yavaş ortaya çıkıyor. Tecrübeli ögretmenlerden sorarak ögreniyorum. Ya da internetten araştırıyorum.” Beden eğitimi öğretmenleri mesleğe başladıklarında lisanstan kaynaklanan eksiklikler nedeniyle kendilerini geliştirme ihtiyacı olduklarını belirtmişlerdir. Öğretim yöntemlerinin yetersiz alımı kategorisinde beden eğitimi öğretmenleri öğretmenliğe başladıklarında bilgi sahibi olduğu konularda bile ögrencilere aktarmada problem yaşadıkları veya bunu nasıl yapacaklarını bilmedikleri konusunu belirtmişlerdir. B.E.Ö.11: "Sporcu gibi yetișmektense daha çok nasıl ögrreteceğimizi ögrenseydik daha iyi olurdu”. Beden eğitimi öğretmenleri öğrenciye konuları aktarmada problem yaşadıkları, öğretim yöntem ve tekniklerini iyi bir şekilde alamadıklarını aynı zaman stajın verimli geçmediğini belirtmişlerdir. Genel kültür derslerini gerekliliği altı boyutunda beden eğitimi öğretmenlerinin bazıları genel kültür derslerini gerekli bazıları ise gereksiz görmektedir. Öğretmenler ifadelerinde, alternatif bazı derslerin koyulabileceğini veya İngilizce ders saatinin arttırılması gerektiğini belirtmişlerdir. Genel kültür derslerini gereksiz gören öğretmenler, bu derslerin yerine daha fazla spor dersi olabileceğini ifade etmişlerdir. Teorik dersleri gerekli görme alt boyutunda öğretmenler görüşmelerde teorik derslerin çok gerekli olduğunu mutlaka programda yer alması gerektiğini ve bir öğretmenin teorik derslerden aldıkları bilgilere sahip olması gerektiğini belirtmişlerdir.

\section{Öğretim Elemanı Yeterliliği Teması}

Öğretim elemanı yeterliliği teması altında kategoriler ve frekansları "Alan bilgisinin eksikliği" ( $\mathrm{f}=15)$, "Öğretim elemanı azlığı" (f=14), "İletişim” (f=6), ve "Hedefe yönelik sınav" ( $\mathrm{f}=5)$ kategorisi olarak dağılım göstermiştir. Alan bilgisinin yeterliliği kategorisinde beden eğitimi öğretmenleri özellikle spor dersine giren öğretim elemanların bir bölümünün ders içeriği bilgisi, ders işleme yöntemleri gibi konularda yetersiz olduklarını bir kısmı da yeterli olduklarını belirtmişlerdir. B.E.Ö.7: "Bazı hocaların basketbola girdiklerini biliyorum. Sonra anatomiye sonra step aerobik dersine giriyor. Bu bence garip. Hepsinde çok iyi olamazsın ki." İfadelerden, bu sorunun öğretim elemanlarının kendi alanı dışında derse girmeleri olduğunu belirtmişlerdir. B.E.Ö.18: "Bence hocalarımız genelde çok kaliteli idi. Profesör ve doçent sayısı fazlaydl. Zaten bizim bölüm eski ve köklü bir okuldu. " Diğer bulgulardan bir tanesi üniversite mezuniyetine göre göre öğretim elemanı yeterliliğinin değişmesidir. Öğretim elemanı azlığı kategorisinde beden eğitimi öğretmenleri okudukları dönemde öğretim elemanlarını sayı olarak yeterli olmadıklarını ve ders yüklerinin fazla olduklarını söylemişlerdir. B.E.Ö.10: "Bazl seçmek istediğimiz dersleri hoca yetersizliğinden dolayı dersleri açamıyorlardı. Tenis dersini seçmek istedim. Hocası olmadı ̆̆ için ders açılmadı." B.E.Ö.12: "Bazl hocaların eksikliği yüzünden bir hoca 3 derse giriyordu onlarda hepsini aynı verimlilikte anlatamıyorlardı." Öğretim elemanı azlığı, öğretim elemanlarının girdikleri ders sayılarının artmasına neden olduğu öğretmenlerin ifadelerinden anlaşılmaktadır. İletişim kategorisinde öğretmenler, okudukları dönemde öğretim elemanları ile genelde iletişimlerinin öğretim elemanının tavır ve kalitelerine göre değiştiğini belirmişlerdir. B.E.Ö.17: "Bu hocanın kalitesiyle paralel iyi hocaysa kendini yenileyen, bakımlı iletişime açık kişi oluyor. Bu bence ne kadar kendini geliştirmiş olmasıyla doğru orantılı olan bir şey alanında iyi olan diğer özellikleri de beraberinde getiriyor." Beden eğitimi öğretmenleri derslerde niteliklerinin iyi olduklarını düşündüğü öğretim elemanlarının iletişimlerinin daha iyi olduklarını söylemişlerdir. Beden eğitimi öğretmenleri, üniversitedeki rehberlik ve danışmanlık hizmetlerinin yetersiz olduğunu, öğretmenlik yaşantısı ile ilgili bilgilendirme yapılması gerektiğini belirtmişlerdir. Eleştiriye açık olma konusunda tam bir genelleme yapmadıklarını, bir kısmının eleştiriye açık bir kısmının ise eleştiriye kapalı öğretim elemanlarının olduğunu ifade etmişlerdir. Hedefe yönelik sınav kategorisinde beden eğitimi öğretmenleri okudukları dönemde özellikle uygulamalı derslerde sınavların farklı olması gerektiğini, sporcu olarak yetişmediklerini, öğretmen olacaklarını belirtmişler, sınavlarında bu mantığa göre olması gerektiğini söylemişlerdir. B.E.Ö.13: "Benim anlamadı̆̆ım üniversiteye uygulamal sinavla seçildik ve belli yetenekte olan kişilerdik bizi spor derslerinde yine iyi top sürebiliyor muyum, iyi koşabiliyor muyum, iyi atabiliyor muyum diye benim performansımı ölçüyorlar. Biz beden ĕğitimi öğretmeni olacă̆ız. Bu becerileri nasıl ögretmemiz gerektiği üzerine bir ĕgitim almallydık. Sürekli bizim performansımızı ölçtüler. $O$ da olsun ama bizim ögreticiliğimiz üzerine bir değerlendirme yapılması gerekti.". Öğretmenler değerlendirme sisteminde bir problem olduğunu ifade etmişlerdir. Sınavlarda öğretim elemanlarının büyük bir çoğunluğunun objektif olduğu tespit edilmiştir. Bazı öğretmenler ise öğretim elemanlarının objektif olmadıklarından yakınmışlardır. 


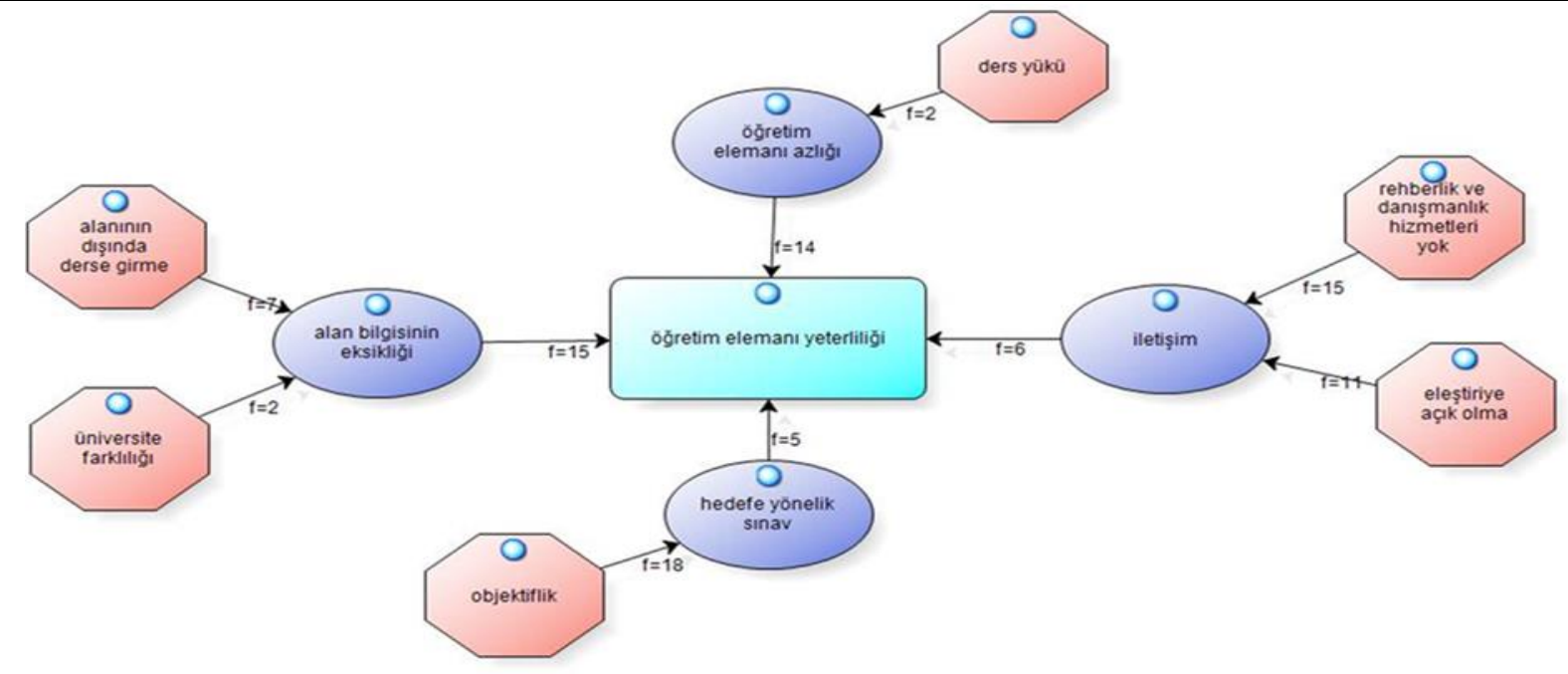

Tesis ve Sosyal İmkânların Yeterliliği teması

Tesis ve Sosyal İmkânların Yeterliliği Teması, "Spor tesislerinin yetersizliği" ( $\mathrm{f}=14)$ ve "Sosyal ve kültürel faaliyet yeterliliği”" ( $\mathrm{f}=12$ ) kategorilerinden oluşmuştur. Spor tesisleri yetersizliği kategorisinde öğretmenler tesislerden yararlanmada sorunlar yaşadıklarını belirtilmiştir. B.E.Ö.10: "Tesisler yetersizdi. Salon ortak kullanımlıydl. Üniversiteye değil bölüme ait tesisler olmalıydl. ” Özellikle dersler dişında tesisleri kullanamadıklarından yakınmışlardır. Dersler dışında tesislerden yararlanmadıklarını içeren ifadeler ortaya çıkmıştır. Bunun sebeplerinden en önemlisinin tesislerin bölüme ait olmaması olduğunu ifade etmişlerdir. Tesislerin üniversitenin genel kullanımına açık olması veya gençlik spor genel müdürlüğünün tesislerinin kullanılması sebebiyle ders dışında spor tesislerinden yararlanamadıklarını düşünmektedirler. B.E.Ö.7: "Tesis konusu bizim dönemde başlı başına bir problemdi. Salon için meslek yüksekokuluna geliyorduk. Atletizm için gençlik sporun stad yüzme için yine merkezdeki havuza geliyorduk. Diğer dersler için tekrar kampüse geliyorduk. Bu konuda çok sorun yaşadık.” Beden eğitimi öğretmenleri öğrenci oldukları dönemde tesislerin kendi bölümlerine ait olmaması nedeniyle dersliklere ve spor tesislerine ulaşım konusunda bazı sıkıntılar yaşadıkları anlaşılmaktadır. Beden eğitimi öğretmenleri tesislerin eksikliği yanında spor malzemelerinin de eksik ve yetersiz olduğunu belirtmişlerdir. Derslerin malzeme eksikliği nedeniyle verimli geçmediğini söylemişlerdir. Bu bulgular beden eğitimi öğretmeni yetiştiren kurumların bazılarının tesis ve malzeme konusunda ciddi problemlerin olduğunu göstermektedir. Sosyal ve kültürel faaliyetlerin kategorisinde beden eğitimi öğretmenleri okudukları dönemde özellikle sporla ilgili bilimsel kongre, sempozyum ve panellerin yeterince yapılmadığını söylemişlerdir. Bu faaliyetlerin daha fazla olması gerektiğini belirtmişlerdir. Bilimsel kongre, panel ve seminer eksikliği kavramının görüşmelerdeki frekansı 10 olarak tespit edilmiştir. Sağlık ve güvenlik tedbirlerinin üniversitelere göre farklılık gösterdiği tespit edilip birçok beden eğitimi öğretmeni hiçbir sağlık önleminin olmadığını söylemişlerdir. Sağlık ve güvenlik tedbirleri kavramının frekansı 12 olarak belirlenmiştir.
Beden eğitimi öğretmenlerinin bazıları üniversite imkânlarının yetersiz olması nedeniyle araştırma yapacakları, sporla ilgili dokümanları bulabilecekleri kütüphanelerin olmamasından ya da yetersiz olduğundan söz etmişlerdir. Sporla ilgili kaynak ve kütüphane yetersizliği kavramının frekans sayısı 3 olarak tespit edilmiştir. Öğretmenler bir kısmı okudukları dönemde kantin ve yemekhanenin yeterli hizmet vermediğini düşünmektedirler. $\mathrm{Bu}$ kavramın frekans sayısı 3 olarak belirlenmiştir. Üniversitelerde bahar şenlikleri dıșında sanatsal ve kültürel faaliyetlerin yeterli olmadığı öğretmenlerin ifadelerden çıkarılabilir. Üniversitenin ve şehir imkânların bu faaliyetlerin yeterli olmamasının sebebi olarak görmektedirler. Sanatsal ve kültürel faaliyetlerin eksikliği kavramı frekans sayısı 7 olarak tespit edilmiştir. 
Şekil 3. Tesis ve Sosyal İmkânların Yeterliliği Teması

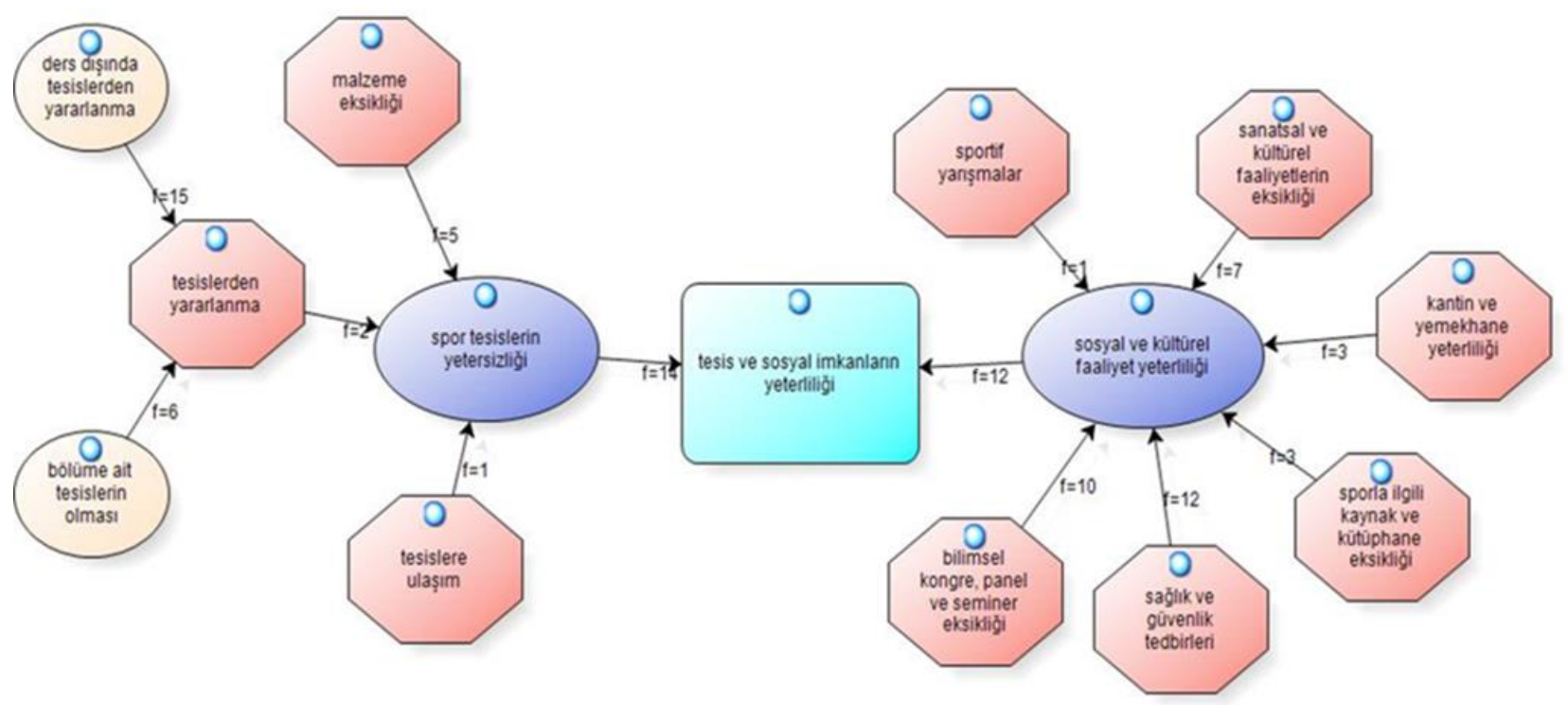

\subsection{Nicel Bulgular}

yeterliliği ile ilgili cinsiyet ve yaşlarına göre farklılığın tespit

Araştırmanın nicel bölümünde beden eğitimi öğretmenlerinin beden eğitimi öğretmenliği bölümlerinin edilmesi amacıyla Mann Whitney U ve Krusskal Wallis testi sonuçları verilmiş̧ir.

Tablo 3. Öğretmenlerin Cinsiyetlerine Göre Mann Whitney U Testi Sonuçları

\begin{tabular}{|c|c|c|c|c|c|c|}
\hline & Cinsiyetler & $\mathrm{n}$ & $\mathrm{x}$ & Ss & Mann-Whitney U & $\mathrm{p}$ \\
\hline \multirow{2}{*}{ Öğretim Programı Yeterliliği } & Erkek & 200 & 3,01 & 0,82 & \multirow{2}{*}{8023,500} & \multirow{2}{*}{0,658} \\
\hline & Kadın & 83 & 2,96 & 0,86 & & \\
\hline \multirow{2}{*}{ Ö̆gretim Elemanı Yeterliliği } & Erkek & 200 & 3,17 & 0,85 & \multirow{2}{*}{8141,500} & \multirow{2}{*}{0,800} \\
\hline & Kadın & 83 & 3,20 & 0,86 & & \\
\hline \multirow{2}{*}{ Tesis Yeterliliği } & Erkek & 200 & 3,16 & 0,64 & \multirow{2}{*}{7797,000} & \multirow{2}{*}{0,421} \\
\hline & Kadın & 83 & 3,09 & 0,62 & & \\
\hline
\end{tabular}

Tablo 3'te beden eğitimi öğretmenlerinin cinsiyetlerine göre beden eğitimi ve spor öğretmenliği bölümü yeterlilik alt boyutları ile ilgili aldıkları puanlar verilmiştir. Öğretim programı yeterliliği alt boyutu incelendiğinde erkek öğretmenlerin puanlarının ( $\bar{x}=3,01)$ kadın öğretmenlerin puanlarından $(\overline{\mathrm{x}}=2,96)$ yüksek olduğu bulunmuştur. Ancak öğretmenlerin cinsiyetlerine göre öğretim programı yeterlilik puanları arasındaki bu fark istatistiksel açıdan anlamlı bulunmamıştır ( $p>0,05)$. Öğretim elemanı yeterliliği alt boyutu incelendiğinde kadın öğretmenlerin puanlarının $(\overline{\mathrm{x}}=3,20)$ erkek öğretmenlerin puanlarından $(\overline{\mathrm{x}}=3,17)$ yüksek olduğu bulunmuştur. Ancak öğretmenlerin cinsiyetlerine göre öğretim elemanı yeterlilik puanları arasındaki bu fark istatistiksel açıdan anlamlı bulunmamıştır $(p>0,05)$. Tesis yeterliliği alt boyutu incelendiğinde erkek öğretmenlerin puanlarının $(\overline{\mathrm{x}}=3,16)$ kadın öğretmenlerin puanlarından $(\bar{x}=3,09)$ yüksek olduğu bulunmuştur. Ancak öğretmenlerin cinsiyetlerine göre öğretim elemanı yeterlilik puanları arasındaki bu fark istatistiksel açıdan anlamlı bulunmamıştır $(\mathrm{p}>0,05)$.

Tablo 4. Beden Eğitimi Öğretmenlerinin Yaşlarına Göre Krusskal Wallis Testi Sonuçları

\begin{tabular}{|c|c|c|c|c|c|c|c|c|c|}
\hline & Yaşlar & $\mathrm{N}$ & $\mathrm{x}$ & SS & Kruskal Wallis H & df & $\mathrm{p}$ & Grup & $\mathrm{P}$ \\
\hline & 30 yaş ve altı & 45 & 2,96 & 0,89 & \multirow{5}{*}{7,803} & \multirow{5}{*}{4} & \multirow{5}{*}{,099 } & & \\
\hline Öğretim & 31-35 yaş & 118 & 2,90 & 0,79 & & & & & \\
\hline Programı & 36-40 yaş & 100 & 3,01 & 0,82 & & & & & \\
\hline \multirow[t]{2}{*}{ Yeterliliği } & 41-45 yaş & 11 & 3,52 & 0,84 & & & & & \\
\hline & 46 yaş ve üzeri (5) & 9 & 3,55 & 0,94 & & & & & \\
\hline \multirow{5}{*}{$\begin{array}{l}\text { Öğretim Elemanı } \\
\text { Yeterliliği }\end{array}$} & 30 yaş ve altı & 45 & 3,21 & 0,74 & \multirow{5}{*}{28,126} & \multirow{5}{*}{4} & \multirow{5}{*}{, $000 *$} & $1-4$ & $0,001 *$ \\
\hline & 31-35 yaş & 118 & 3,39 & 0,81 & & & & $1-5$ & $0,001 *$ \\
\hline & $36-40$ yaş & 100 & 3,11 & 0,87 & & & & $2-4$ & $0,000 *$ \\
\hline & 41-45 yaş & 11 & 2,31 & 0,72 & & & & $2-5$ & $0,000 *$ \\
\hline & 46 yaş ve üzeri (5) & 9 & 2,23 & 0,51 & & & & $3-5$ & $0,003 *$ \\
\hline \multirow{5}{*}{ Tesis Yeterliliğ $i$} & 30 yaş ve altı & 45 & 3,04 & 0,54 & \multirow{5}{*}{12,114} & \multirow{5}{*}{4} & \multirow{5}{*}{, $017 *$} & \multirow{5}{*}{$2-5$} & \multirow{5}{*}{$0,003^{*}$} \\
\hline & 31-35 yaş & 118 & 3,21 & 0,65 & & & & & \\
\hline & $36-40$ yaş & 100 & 3,18 & 0,64 & & & & & \\
\hline & 41-45 yaş & 11 & 2,83 & 0,74 & & & & & \\
\hline & 46 yaş ve üzeri (5) & 9 & 2,63 & 0,41 & & & & & \\
\hline
\end{tabular}


Tablo 4'te beden eğitimi öğretmenlerinin yaşlarına göre beden eğitimi ve spor öğretmenliği bölümü yeterlilik alt boyutları ile ilgili aldıkları puanlar verilmiştir. Öğretim programı yeterliliği alt boyutu incelendiğinde öğretmenlerin yaşlarına göre aldıkları puanlar arasında istatistiksel açıdan anlamlı fark bulunmamıştır $(\mathrm{p}>0,05)$. Öğretim elemanı yeterliliği ve tesis yeterliliği alt boyutu incelendiğinde öğretmenlerin yaşlarına göre aldıkları puanlar arasında istatistiksel açıdan anlamlı fark bulunmuştur. Öğretim elemanı yeterliliği boyutundaki farkın hangi iki grup arasında kaynaklandığını belirlemek amacıyla Bonferroni düzeltmeli Mann-Whitney U Testi yapılmıştır. Yapılan ikili karşılaştırmalar sonucunda bu farklılıkların, 30 yaş ve altı ile 41-45 yaş, 30 yaş ve altı ile 46 yaş ve üzeri, $31-35$ yaş ile 41 45 yaş, $31-35$ yaș ile 46 ve $36-40$ yaş ile 46 yaş ve üzeri grupları arasında olduğu tespit edilmiştir. Tesis yeterliliği alt boyutu incelendiğinde öğretmenlerin yaşlarına göre aldıkları puanlar arasında istatistiksel açıdan anlamlı fark bulunmuştur. Yapılan ikili karşılaştırmalar sonucunda bu farklılığın, 31-35 yaş ile 46 yaş ve üzeri grupları arasında kaynaklandığı görülmüştür.

\section{Sonuç ve Öneriler}

Beden eğitimi öğretmenleriyle yapılan görüşmeler sonucunda öğretim programı yeterliliği teması sonucu ortaya çıkmıştır. Beden eğitimi öğretmenleri mesleklerine başladıkları ilk yıllarda bir takım mesleki problemler yaşadıklarını ifade etmişlerdir. Öğretmenler, bunun nedeni olarak lisans eğitimi ile Milli Eğitim Bakanlığındaki eğitimin farklılıkları göstermişlerdir. Bulca, Saçlı, Kangalgil ve Demirhan (2012) beden eğitimi öğretmenlik programı ile Milli Eğitim Bakanlığına bağlı okullarda okutulan beden eğitimi dersi içeriğinin paralellik göstermesi gerektiğini ifade etmişlerdir. Harmandar (2010), Avrupa birliğine bağlı ülkelerin ders programlarını incelediği çalışmasında Türkiye'deki beden eğitimi bölümlerinin kredi sayılarının diğer ülkelere göre daha az olduğu tespit etmiştir. Öğretmen adaylar1, NSA 240, Loughborough 360 ve Thrace Democritus Üniversitelerinde 240 kredi alarak eğitimlerini tamamlamaktadırlar. Türkiye'de ise 158 krediden oluşmaktadır. Yalız (2006) çalışmasında alan bilgisi seçmeli derslerin beden eğitimi öğretmenliği bölümündeki öğrencilerin ihtiyaç ve isteklerine göre seçmeli derslerin açılmadığı sonucuna ulaşmıştır. Uğraş, Güllü, Eroğlu ve Özen (2017) beden eğitimi öğretmenlerinin lisans döneminde evrak ve dosyalar ile ilgili dersler verilmesi gerektiğini, bu bilgilerin verilmemesinden kaynaklı öğretmenlerin mesleğin ilk yıllarında problemler yaşadıklarını tespit etmişlerdir. Öğretmen adayı sınıf yönetimi konusunda da bir deneyim kazanmaktadır. Yapılan çalışmalarda öğretmen adaylarının stajın; öğrencilerle ilişkiler, eğitim ortamı, öğretim yöntemlerini sahada uygulama ve deneyim kazanma konusunda önemli bir role sahip olduğu sonucuna ulaşmışlardır (Demircan, 2007; Özay Köse, 2014; Yenilmez ve Ata, 2012). Fakat araştırmalarda stajın verimliliği ile ilgili bir takım problemlerin yaşandığı ile ilgili sonuçlara ulaşılmıştır (Atmış, 2013; Eraslan, 2009; Yılmaz, 2011). Bu araştırma sonuçlarına göre beden eğitimi öğretmenleri lisanstaki öğretim programından kaynaklı sorunlar yaşadıklarını, bunun nedeni olarak iyi bir eğitim alamadıklarını ifade etmişlerdir. $\mathrm{Bu}$ sonuç diğer araştırma bulguları ile paralellik göstermektedir. Beden eğitimi öğretmenlerinin lisans döneminde staj ya da diğer bir deyişle okul deneyimi dersinin yeterli olmamasından kaynaklı bir takım sorunlar yaşamamaları için öğretmenlik lisans programında düzenlemelerin yapılması gerektiğinin bir göstergesi olabilir.

Öğretim elemanı yeterliliği teması sonuçlarına göre öğretim elemanı niteliği ve niceliği konusunda problemlerin yaşandığı sonucuna ulaşılmıştır. Can ve Durukan (1999) Cumhuriyetten günümüze öğretmen yetiştirilmesi çalışmasında öğretmen yetiştiren kurumların fiziki yetersizlerinden ve kapasitesinin üzerinde öğrenci alınmaması gerektiğinden bahsetmişler. Yalız (2006) çalışmasında öğrencilerin istedikleri dersi seçemediği sonucuna ulaşmıştır. Bunun nedeni öğretim elemanı sayısı ile ilgili sıkıntıların var olduğunun bir göstergesidir. Koçak, Tuncel ve Tuncel (2011) yaptıkları SWOT analizinde beden eğitimi ve spor yüksekokullarının zayıf yönleri içerisinde nitelikli öğretim elemanı eksikliği bulgusuna ulaşmıştır. Demirhan ve Açıkada (1997) Türkiye ve Avrupa ülkelerinde beden eğitimi yetiştiren kurumlar üzerine yaptığı çalışmada Türkiye'de öğrenci başına düşen öğretim eleman sayısının Avrupa ülkelerine göre düşük olduğunu belirtmiş̧lerdir. Koçak ve Tuncel (2011) öğretim elemanı başına düşen öğrenci sayısının fazla olduğunu ifade etmişlerdir. Dohman ve Özmaden de (2008) yetişmiş öğretim elemanı eksikliği olduğunu belirtmişlerdir. Son yıllarda hızla açılan devlet ve vakıf üniversiteleri beraberinde nitelik sorunlarını da getirmiştir. Açılan bölümlerin ihtiyaçlarını karşılayacak yetişmiş öğretim elemanı sayısı ve niteliği soru işareti olarak göze çarpmaktadır. $\mathrm{Bu}$ nedenler öğretmen yetiştirmede nitelik sorununu da beraberinde getirmektedir.

Tesis ve sosyal imkânlar temasında beden eğitimi öğretmenleri genellikle tesis ve sosyal imkânlar konusunda problemler yaşadıklarını ifade etmişlerdir. Birçok araştırma beden eğitimi ve spor eğitimi veren kurumların, derslik, laboratuvar, araç - gereç, kütüphane, spor salonu, yüzme havuzu ve benzeri sorunları olduğu sonucuna ulaşmışlardır (Açıkada, 1992; Can ve Durukan, 1999; Dohman ve Özmaden, 2008; Temel ve Sunay, 2002; Yanık, 2007). Beden eğitimi yetiştiren bölümlerin hızla artması, gerekli altyapının ve şartların sağlanmaması öğretmen yetiştirmede nitelik sorunları da yanında getirmiştir.

$\mathrm{Bu}$ sonuçlar doğrultusunda şu önerilerde bulunulabilir.

- Spor eğitimi veren kurumların tesis, öğretim elemanı, program ihtiyaçlarının eksikliklerin belirlenmesi sağlanabilir.

- Öğretim elemanı yeterliliğini nitelik ve nicelik bakımından iyileştirici düzenlemeler yapılması sağlanabilir. Örnek olarak öğretim elemanı alımının artırılması ve öğretim üyesi yeterli olan üniversitelerin öğretim elemanı yetiştirmede daha etkin kullanılması sağlanabilir.

- Öğretim programlarının toplumun, Milli Eğitim Bakanlığının ve çağın gereklerine uygun olarak ihtiyaçların belirlenmesi ve buna göre düzenlenmesi önerilebilir.

- Beden eğitimi ve spor öğretmenliği bölümlerinde ders çeşitliliğinin artırılması ve seçmeli ders sayısının artırılması önerilebilir.

- Bölümlerin açılma kriterler belirlenirken, fiziki donanım, öğretim elemanları ve sosyal-kültürel kriterleri getiren bölümlerin açılmasına onay verilmesi sağlanabilir. 


\section{Kaynakça}

Açıkada, C. (1992). Beden eğitimi ve spor öğretmeni yetiştirmede müfredat programı sorunları. Spor Bilimleri Dergisi, 4(3), 3-13.

Atmiş, S. (2013). Sinıf öğretmeni adaylarının öğretmenlik uygulaması sürecini değerlendirmelerine yönelik görüşlerinin incelenmesi. Yüksek Lisans Tezi. Trabzon: Karadeniz Teknik Üniversitesi.

Barlı, Ö., Bilgili B., Çelik, S., \& Bayrakçeken, S. (2005). İlköğretim okul öğretmenlerinin motivasyonları: farklılıkların ve sorunların araştırılması. Atatürk Üniversitesi Sosyal Bilimler Elektronik Dergisi, 5(1), 391-417.

Bilge, N. (1989). Türkiye’de beden eğitimi öğretmeninin yetiştirilmesi. Ankara: Kültür Bakanlığı Yayınları.

Bulca Y., Saçlı, F., Kangalgil, M., \& Demirhan, G. (2012). Beden eğitimi öğretmenlerinin öğretmen yetiştirme programına ilişkin görüşleri. Ĕgitim ve Bilim Dergisi, 37(165), 81-92.

Büyüköztürk, Ş. (2004). Sosyal bilimler için veri analizi el kitabı. Ankara: Pegem Akademi Yayıncılık.

Büyüköztürk, Ş., Çakmak, E. K., Akgün, Ö. E., Karadeniz, Ş., \& Demirel, F. (2017). Bilimsel araştırma yöntemleri. Ankara: Pegem Akademi Yayıncılık.

Can, S., Can, Ş., \& Durukan, E. (1999). Cumhuriyetten günümüze öğretmen ve öğretmenin yetiştirilmesi. Atatürk Üniversitesi Beden Ĕgitimi ve Spor Bilimleri Dergisi, 1(1), 61-70.

Creswell, J. W. (2016). Nitel araştırma yöntemleri: beş yaklaşıma göre nitel araştırma ve araştırma deseni. Ankara: Siyasal Kitabevi.

Creswell, J. W., \& Clark, V. L. P. (2015). Karma yöntem araştırmaları: tasarımı ve yürütülmesi. (İkinci Baskıdan Çeviri) (Cev. Ed. Y. Dede ve S. B. Demir). Ankara: Anı Yayınc1lık.

Çiçek, Ş., \& Bizati, Ö. (2002). Stajyer beden eğitimi öğretmenliğinde rehberlik sorunu: diğer alandan mi?, diğer okuldan mı?. Gazi Beden Eğitimi ve Spor Bilimleri Dergisi, 7(3), 25-34.

Demircan, C. (2007). Okul deneyimi II dersine yönelik öğrenci görüşlerinin incelenmesi (Mersin Üniversitesi Örneği). Mersin Üniversitesi Ĕ̆itim Fakültesi Dergisi, 3(2), 119-132.

Demirhan G. (2003). Beden eğitimi öğretmenlerinin beden eğitimi ve spora ilişkin felsefi görüşleri. Spor Bilimler Dergisi, 13(2), 38-66.

Demirhan, G., \& Açıkada, C. (1997). Türkiye ve Avrupa ülkelerinde beden eğitimi öğretmeni yetiștiren bazı yükseköğretim kurumlarının öğrenci, öğretim elemanı ve dersler boyutuyla karşılaştırılması. Spor Bilimleri Dergisi, 8(2), 4-25.

Doğan, S., \& Koçak, O. (2014). Okul yöneticilerinin sosyal iletişim becerileri ile öğretmenlerin motivasyon düzeyleri arasındaki ilişki. Kuram ve Uygulamada Ĕ̈itim Yönetimi, 20(2), 191-216.
Dohman, Z., \& Özmaden, M. (2008). Beden eğitimi ve spor öğretmenliği bölümlerinde öğretmen yetiştirme sorunlar1. Atatürk Journal of Physical Education and Sport Science, 10(4), 3-17.

Eraslan, A. (2009). İlköğretim matematik öğretmen adaylarının öğretmenlik uygulaması üzerine Görüşleri. Necatibey Eğitim Fakültesi Elektronik Fen ve Matematik Eğitimi Dergisi, 3(1), 207-221.

Friedman, E. D. (1983). The Pupils image of the physical education teacher and suggestions for changing attitudes in teacher training. International Journal of Physical Education, 20(2), 15-18.

Koçak, F., Tuncel, S. D., \& Tuncel, F. (2011). Beden eğitimi ve spor yüksekokullarında stratejik yönetim uygulaması (Swot Analizi). Uluslararası Hakemli Akademik Sosyal Bilimler Dergisi, 1(2), 85-92.

Merriam, S. B. (2015). Qualitative research a guide to design and implementation. Çeviri: Turan S. Nitel Araştırma Desen ve Uygulama İçin Bir Rehber. Ankara: Nobel Yayıncilık.

Miles, B. M., \& Huberman, M. A. (1994). Qualitative data analysis: an expanded sourcebook. 2nd Edition. California: SAGE Publications.

ÖSYM (2017). ÖSYS Yükseköğretim Programlarına Ek Yerleştirme Kılavuzu. (Erişim Tarihi: 13.02.2017), http://www.osym.gov.tr/TR,13337/2017-osys-ekyerlestirme--kilavuz-ve-tablolar.html

Patton, M. Q. (2002). Qualitative interviewing. In Qualitative research and evaluation methods. Thousand Oaks, Ca: Sage. 